\title{
Selecting Reference Cities for i-Tree Streets
}

\author{
E. Gregory McPherson
}

\begin{abstract}
The i-Tree Streets (formerly STRATUM) computer program quantifies municipal forest structure, function, and value using tree growth and geographic data from sixteen U.S. reference cities, one for each of sixteen climate zones. Selecting the reference city that best matches a subject city is problematic when the subject city is outside the U.S., lays on the border between two climate zones, has a different climate, or tree species composition because of differences in elevation, urban morphology, and environmental quality. A systematic process for selecting the best match is described and illustrated for Lisbon, Portugal. Selection criteria are tree species composition, heating and cooling degree days, and annual precipitation. Raw and difference values for each criterion are normalized to range from 0 to 10 using linear interpolation. The coefficient for each criterion is weighted to reflect its relative importance. The Root Mean Square Error (RMSE) is calculated and the reference city with the lowest value is the best match for the subject city. The state of California's reference cities of Modesto (RMSE $=2.41$ ) and Claremont (2.71) proved to be the best match for Lisbon when coefficients were unequally weighted.

Key Words. Benefit-Cost Analysis; i-Tree Streets; Municipal Forests; Street Tree Inventory; Urban Forest Valuation.
\end{abstract}

The USDA Forest Service released STRATUM (Street Tree Resource Analysis Tool for Urban Forest Managers) to the public in August 2006 as one component of the i-Tree software suite. Based on 20 years of urban forest science, STRATUM (hereafter referred to as i-Tree Streets) was developed for urban foresters, municipal arborists, tree organizations, landscape architects, contractors, planners, environmental consultants, and others interested in analyzing the benefits and costs of municipal forests (McPherson 1992; McPherson and Simpson 2002; Maco and McPherson 2003; McPherson et al. 2005). The computer program helps users understand the structure, function, and management needs of their street trees, calculate the environmental and aesthetic benefits the trees provide, and determine the dollar value for those benefits. iTree Streets was designed to help users improve tree management, and to show decision-makers and residents alike that urban forests are an essential part of healthy, well-balanced communities.

The U.S. was divided into sixteen national climate zones by aggregation of 45 Sunset climate zones (Figure 1) (Brenzel 1997). Sunset zones were aggregated based on factors that influence plant distribution, such as length of growing season and minimum temperature, as well as building energy use patterns (i.e., number of days with highs of $32^{\circ} \mathrm{C}$ or higher). Also, ecoregions developed by Bailey (2002) and Breckle (1999) were consulted to delineate climate zone boundaries. Termed "reference city," one city was selected for intensive study within each climate zone. Criteria for selection included: 1) an updated tree inventory (20,000 to 100,000 street/park trees), 2) accurate information on planting dates for aging a sample of approximately 900 trees by the city forester, and 3) large, old trees present in the community. In each reference city, 30 to 60 trees from each of the 22 major tree species were aged and measured [e.g., diameter at breast height (dbh), height, crown diameter]. Crown volume and leaf area were estimated from computer processing of tree-crown images obtained by using a digital camera. The method has shown greater accuracy than other techniques ( $\pm 20 \%$ of actual leaf area) in estimating crown volume and leaf area of open-grown trees (Peper and McPherson 2003). Linear regression was used to fit predictive models with dbh as a function of age for each of the 20 sampled species. Predictions of leaf surface area, crown diameter, and height metrics were modeled as a function of dbh using best-fit models. Geographic data were collected for use in i-Tree Streets' numerical models such as temperature, precipitation, air pollutant concentrations, and fuel mix for energy production.

The program uses this background reference city data to model the growth, benefits, and costs of street trees. Users import data collected in a sample or complete inventory conducted by professionals or trained volunteers, and enter community specific information (e.g., program management costs, city population, price of residential electricity) to customize the benefit-cost data. The program calculates the costs associated with planting and managing the trees and quantifies the value of annual benefits including carbon dioxide sequestration, energy conservation, air quality improvement, stormwater control, and increase in property value (Scott et al. 1998; Xiao et al. 2000; Simpson 2002). Results are presented as easy-to-read and easy-to-use graphs, charts, and tables.

$\mathrm{i}$-Tree Streets is offered free to the public and supported by contributions from the i-Tree (2009) public/private partnership: USDA Forest Service, State and Private Forestry; Davey Tree Expert Company; International Society of Arboriculture, Society of Municipal Arborists; Arbor Day Foundation, and Casey Trees (www.itreetools.org). Results generated by Streets were used by New York City's forestry director to demonstrate the social, economic and environmental value of increasing investment in the municipal forest. The result was an impressive USD \$380 


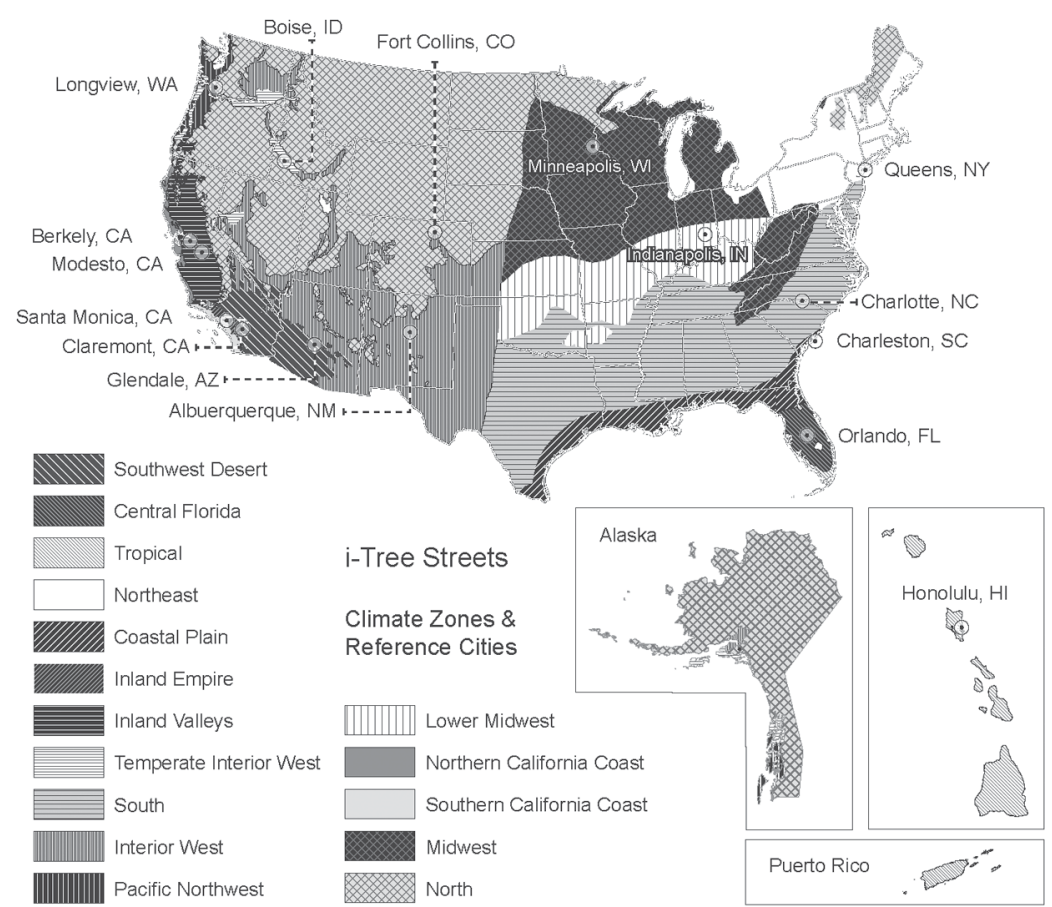

Figure 1. i-Tree Streets climate zones were aggregated from 45 Sunset climate zones into sixteen zones. Each zone has a reference city where geographic and tree growth data were collected.

million in new funds for urban forestry over the next ten years (Kling 2008). The National Tree Benefit Calculator (2009) combines tree benefit data from i-Tree Streets with a user-friendly interface to display the value of individual street trees (www. treebenefits.com). i-Tree Streets is being used to demonstrate the social, environmental, and economic value of investing in "green infrastructure," and is generating many requests to expand application to Asian, European, Canadian, and Australian cities.

One of the first questions i-Tree Streets users face is choice of climate zone. Once a zone is selected, the software loads a list of common tree species and benefit and cost data based on research conducted in that zone's reference city. Other than displaying a map of the U.S. showing the sixteen climate zones, the interface does not provide guidance for determining which reference city to select. For example, what criteria should be used to select a climate zone when the subject city rests on the border of two zones? Which climate zone and reference city is the best match if the subject city has a substantially different climate than the reference city because of elevation, location near a large water body, or other geographic features?

It is recognized that relying on reference city data is a poor substitute for applying local data. Results are, at best, first-order approximations due to extrapolation of data from reference city to subject city. Inaccuracies can be magnified when i-Tree Streets is applied outside the U.S. However, the cost of conducting a reference city analysis, an estimated $\$ 250,000$ per city, makes it impossible for every city to afford the accuracy obtained with the intensive reference city analysis. It is proposed that within the next few years i-Tree Streets and i-Tree Eco, a software application within i-Tree Streets, will be integrated into a single, turn-key program that contains geographic data for major cities around the world. In the meantime, users will obtain the best results from i-Tree Streets by selecting the reference city that best matches their local conditions.

The objective of this paper is to describe and demonstrate a systematic process for selecting the "best fit" reference city. The paper begins with a background to the approach and describes the selection criteria. This analysis will conclude with an illustration of the reference city selection process applied to Lisbon, Portugal.

\section{APPROACH}

\section{Background}

The primary goal behind finding the best match is to produce benefit estimates that are as accurate as possible. In other words, total benefits obtained using reference city $X$ are closer to actual than obtained using reference city $\mathrm{Y}$ or Z. Because i-Tree Streets is a simulation model, its results can only approximate reality. Determining the magnitude and source of errors is difficult due to the complex collection of input data and simulation models. A systematic analysis of the sensitivity of i-Tree Streets' output to the probabilistic range of possible input values has not been undertaken. However, all model inputs have been identified with errors grouped into six categories.

1. Sampling error. A sampling error expresses how well a tree sample reflects the actual tree population. There is no sampling error for a complete inventory.

2. Formulaic error. Errors of this type are related primarily to formulation and application of tree growth models. Within-class errors result from using dbh class midpoints to quantify benefits, when in reality tree sizes may be distributed throughout each size class. Tree size and growth errors are confidence intervals for each dimension that depict increasing variability with size. Species assignment errors result from matching species not sampled to one of the 22 species sampled in the reference city. The magnitude of this error depends on the proportion of population assigned, as well as goodness of fit in terms of matching sizes and annual growth for leaf area, dbh, and other size parameters.

3. Pricing errors. These are errors concerning the selection of values for pricing benefits and costs.

4. Resource unit errors. Resource unit or RU (engineering units such as cubic meters of rainfall intercepted), model errors are related to selection of input data, parameterization of individual models that produce RUs (e.g., building energy use, pollutant deposition, biomass formulas), choice of adjustment factors (e.g., adjacent shade, VOC emission rates), and their assignment to species.

5. Temporal errors. These are errors related to the selection of a particular year of input data. Different years may be used for different numerical models.

6. Spatial errors. Errors related to using data separated by some distance from the region of interest, the use of point measurements of air quality concentrations, precipitation, and other meteorological data for a large area.

Sources of errors that pertain to reference city selection are formulaic: species assignment errors due to a lack of sampled tree species and inaccurate tree dimensions. Also, spatial errors result 
in inaccurate estimates when reference city meteorological and other geographic data are not representative of the subject city.

\section{Criteria}

The approach adopted here attempts to simplify the selection process by limiting the analysis to several criteria: species composition, heating and cooling degree days, and annual precipitation. These criteria were selected because the data are widely available and highly relevant to tree benefit estimation. The approach can include other criteria, such as air pollutant concentrations. For example, if the subject city has very clean air, selecting a reference city with unclean air will result in overestimates of pollutant deposition. However, substantial resources may be required to obtain and manipulate raw data to derive useful indicators for comparison purposes.

\section{Tree species composition}

Matching tree species composition is a priority because tree benefits are linked to species-specific size variables such as leaf area and biogenic volatile organic compound (BVOC) emission rates. Matching involves comparing the relative abundance of the predominant species in the subject city with the values for the approximately 22 species measured in each reference city (see Appendix). The goal is to find the reference city whose measured trees best match with the subject city population. By summing the percentage of each matching species in the subject city inventory, the relative suitability of reference cities can be compared numerically. Also, matches for species that are most abundant are more important than matches for less abundant species. As shown in the following Lisbon example, a species-to-species match is most desirable, but a genus-to-genus match is suitable when different species of the same genus have similar growth rate, habit, and mature size.

The untested assumption is that i-Tree Streets results will be more accurate as the percentage of the population modeled with measured growth curves increases. The species assignment error is reduced by increasing the proportion of population assigned to reference city species with growth curves. However, tree species matching is not a guarantee that tree size and growth data will be accurate. Matching does make it more likely that the tree's mature size, leaf surface area, foliation period, crown density, and BVOC emissions rate are modeled appropriately.

\section{HDDs and CDDs}

Heating cooling degree days and cooling degree days (HDDs and CDDs) reflect annual air temperature patterns and are indicators of building energy heating and cooling loads. These indicators are important because trees influence heating and cooling loads by attenuating irradiance, reducing wind speed, and modifying air temperature. A close match with a reference city suggests that modeled energy effects of trees will be more reliable than results from a poor match. A close match is most important in extremely hot and cold climates, where energy benefits can be substantial. Also, energy savings influence air quality and carbon dioxide benefits because of associated emission reductions from power plants. A good match is more desirable in regions that consume fossil fuels with high emission factors (e.g., coal) to produce electricity compared with regions with electricity produced from hydro and nuclear power.

HDDs and CDDs are calculated from hourly Typical Meteorological Year data used to simulate effects of trees on building energy performance in each of the sixteen reference cities (Table 1). HDDs and CDDs are presented with different base temperatures $\left(15.5^{\circ} \mathrm{C}, 18^{\circ} \mathrm{C}, 18.3^{\circ} \mathrm{C}\right)$, with the base temperature defined as the air temperature below or above which a building needs heating or cooling. More information on degree days and values for most cities can be found on the internet online at Degree Days (2009).

\section{Annual precipitation}

Annual precipitation affects the amount of rainfall interception by tree crowns. Although the seasonality, intensity, and duration of rainfall events are important factors in numerical modeling of interception, information on annual precipitation is the most widely available indicator for comparison purposes. Generally, interception will be greater in areas with more precipitation than in areas with less precipitation. A close match is most important in very wet regions, where interception is substantial and more accurate modeling results are desired. Similarly, a poor match for a very dry region could result in overestimates of interception.

Table 1. Annual Heating Degree Days (HDDs) and Cooling Degree Days (CDDs) for sixteen U.S. reference cities with base temperatures in degrees Centigrade.

\begin{tabular}{|c|c|c|c|c|c|c|}
\hline Reference City & $\begin{array}{l}\text { HDD } \\
15.5^{\circ} \mathrm{C}\end{array}$ & $\begin{array}{l}\text { CDD } \\
15.5^{\circ} \mathrm{C}\end{array}$ & $\begin{array}{l}\text { HDD } \\
18^{\circ} \mathrm{C}\end{array}$ & $\begin{array}{l}\mathrm{CDD} \\
18^{\circ} \mathrm{C}\end{array}$ & $\begin{array}{l}\text { HDD } \\
18.3^{\circ} \mathrm{C}\end{array}$ & $\begin{array}{l}\mathrm{CDD} \\
18.3^{\circ} \mathrm{C}\end{array}$ \\
\hline Albuquerque, NM & 1,836 & 1,119 & 2,352 & 723 & 2,416 & 677 \\
\hline Berkeley, CA & 935 & 209 & 1,682 & 44 & 1,786 & 39 \\
\hline Boise, ID & 2,596 & 680 & 3,242 & 414 & 3,325 & 387 \\
\hline Charleston, SC & 803 & 1,728 & 1,171 & 1,183 & 1,221 & 1,124 \\
\hline Charlotte, NC & 1,377 & 1,355 & 1,832 & 898 & 1,891 & 847 \\
\hline Claremont, CA & 280 & 577 & 791 & 162 & 872 & 134 \\
\hline Fort Collins, $\mathrm{CO}$ & 2,620 & 660 & 3,252 & 379 & 3,332 & 349 \\
\hline Glendale, AZ & 353 & 2,866 & 602 & 2,203 & 637 & 2,128 \\
\hline Honolulu, HI & 0 & 3,438 & 0 & 2,526 & 0 & 2,416 \\
\hline Indianapolis, IN & 2,507 & 886 & 3,079 & 546 & 3,153 & 510 \\
\hline Minneapolis, MN & 3,721 & 662 & 4,354 & 383 & 4,436 & 355 \\
\hline Modesto, CA & 921 & 1,556 & 1,378 & 1,100 & 1,439 & 1,052 \\
\hline Queens, NY & 2,174 & 938 & 2,746 & 597 & 2,819 & 560 \\
\hline Santa Monica, CA & 253 & 831 & 644 & 310 & 710 & 266 \\
\hline Longview, WA & 1,716 & 427 & 2,381 & 180 & 2,468 & 157 \\
\hline Orlando, FL & 121 & 2,660 & 265 & 1,891 & 289 & 1,806 \\
\hline
\end{tabular}


Annual precipitation for reference cities is defined as the total amount of precipitation used in the i-Tree Streets program's calculations of tree interception (Table 2). The year selected for calculating interception had a full complement of hourly meteorological data, and total precipitation was relatively similar to the 30-year average. While many sources exist, average annual precipitation data for most cities can be obtained online at World Weather (2009).

\section{Analysis}

To determine which reference city (RC) best matches the subject city (SC) the analyst calculates the root mean squared error (RMSE) for each reference city. The city with the lowest RMSE is the best match. The RMSE is calculated as:

$\mathrm{RMSE}=\mathrm{SQRT}\left[\mathrm{a} *\left(\mathrm{HDD}_{\mathrm{SC}}-\mathrm{HDD}_{\mathrm{RCi}}\right)^{2}+\mathrm{b} *\left(\mathrm{CDD}_{\mathrm{SC}}-\mathrm{CDD}_{\mathrm{RCi}}\right)^{2}\right.$ $\left.+\mathrm{c} *\left(\mathrm{AP}_{\mathrm{SC}}-\mathrm{AP}_{\mathrm{RC}}\right)^{2}+\mathrm{d} * \mathrm{TM}_{\mathrm{RCi}}{ }^{2}\right]$

where,

$\mathrm{HDD}_{\mathrm{SC}}$ and $\mathrm{HDD}_{\mathrm{RCi}}$ are Heating Degree Days for the subject city and reference city $\mathrm{i}$

$\mathrm{CDD}_{\mathrm{SC}}$ and $\mathrm{CDD}_{\mathrm{RCi}}$ are Cooling Degree Days for the subject city and reference city $i$

$\mathrm{AP}_{\mathrm{SC}}$ and $\mathrm{AP}_{\mathrm{RCi}}$ are annual precipitation for the subject city and reference city $i$

$\mathrm{TM}_{\mathrm{RCi}}$ is the percentage of tree species/genera that match for reference city $\mathrm{i}$ (whole number)

$\mathrm{a}, \mathrm{b}, \mathrm{c}$, and $\mathrm{d}$ are nonnegative coefficients that add to 1.0 and express the relative importance of each criterion.

This approach requires two-steps. First, raw and difference values for each criterion are normalized so that they range from 0 to 10 . Lower values indicate a better match with the reference city than higher values. The second step weights each of the four criteria based on its relative importance. It is recognized that the Tree Match criterion is fundamentally different than the others because the raw value remains the value of interest. For the other criteria, the value of interest is a difference value obtained by subtracting reference city raw values from subject city raw values. Because the Tree Match values are unique, the types of statistical analyses that can be conducted to identify the best match are limited.

First, to normalize data the ranges of raw values are identified for each criterion and 10 equal intervals are calculated. Each of the raw and difference values are normalized and given a value between 0 and 10 . Linear interpolation is used to calculate the normalized values.

The second step is to assign a weight value to each coefficient that reflects its relative importance. For example, if the criteria are equally important, 0.25 is assigned to each of the four coefficients. The coefficient values must sum to 1.0. Factors influencing the relative importance of each criterion include extent of annual tree growth, severity of the climate, seasonality of rainfall, and total amount of annual rainfall. For example, in a northern latitude city with cold, snowy winters and cool, dry summers, it is more important to match HDDs than CDDs or annual precipitation. In a coastal region with mild temperatures and much rainfall, it is more important to match annual precipitation than HDDs and CDDs.

Table 2. Annual precipitation and location for sixteen U.S. reference cities.

\begin{tabular}{llll}
\hline Reference City & Precip. $(\mathrm{mm})$ & Latitude & Longitude \\
\hline Albuquerque, NM & 250 & 35.0844909 & -106.6511367 \\
Berkeley, CA & 564 & 37.8715926 & -122.272747 \\
Boise, ID & 417 & 43.612631 & -116.211076 \\
Charleston, SC & 1,555 & 32.7765656 & -79.9309216 \\
Charlotte, NC & 1,426 & 35.2270869 & -80.8431267 \\
Claremont, CA & 523 & 34.0966764 & -117.7197785 \\
Fort Collins, CO & 452 & 40.5852602 & -105.084423 \\
Glendale, AZ & 174 & 33.5386523 & -112.1859866 \\
Honolulu, HI & 392 & 21.3069444 & -157.8583333 \\
Indianapolis, IN & 1,110 & 39.767016 & -86.156255 \\
Minneapolis, MN & 622 & 44.9799654 & -93.2638361 \\
Modesto, CA & 315 & 37.6390972 & -120.9968782 \\
Queens, NY & 1,041 & 40.7498243 & -73.7976337 \\
Santa Monica, CA & 570 & 34.0194543 & -118.4911912 \\
Longview, WA & 1,059 & 45.6387281 & -122.6614861 \\
Orlando, FL & 1,367 & 28.5383355 & -81.3792365 \\
\hline
\end{tabular}

\section{LISBON, PORTUGAL EXAMPLE}

Lisbon, Portugal serves to demonstrate application of the approach to select the best matching reference city. Also, it provides opportunity to discuss how the relative importance of each criterion is assessed and values assigned to its coefficient.

Lisbon, the capital city of Portugal, has approximately 2.6 million inhabitants and a Mediterranean climate that allows a large number of tree species to thrive. Lisbon (latitude 38.7071631, longitude -9.135517) is located along the Tagus River, and its climate is influenced by the nearby Atlantic Ocean. The annual temperature cycle is relatively mild, with cool winters and warm summers. During summer, temperatures frequently reach $30^{\circ} \mathrm{C}$ or above. Winters are wet and windy, temperatures averaging around $10^{\circ} \mathrm{C}$. Annual precipitation throughout the region ranges from 500 to $760 \mathrm{~mm}$ annually, with most precipitation from October through April.

\section{Comparable Reference Cities}

Initially, the number of candidate reference cities is pared down from sixteen by excluding cities that are obvious mismatches and cities with similar values for the selection criteria. Comparing reference city data (Appendix; Tables 1-2) with values for Lisbon, Portugal (Table 3) indicate annual rainfall (622 and $702 \mathrm{~mm}$, respectively) and CDDs (383 and 474, respectively), in Minneapolis, MN, are good matches with Lisbon. CDDs and the tree species composition in Fort Collins, CO, also have much in common with Lisbon (Table 3). Claremont, Santa Monica, and Modesto, CA, share Lisbon's Mediterranean climate. HDDs in Charleston, SC, closely match HDDs in Lisbon (1,171 and 1,084, respectively).

Six reference cities passed this initial screening. Fort Collins, Colorado, rests at the foot of the Rocky Mountains (elevation $1,500 \mathrm{~m}$ ) and has a semi-arid climate. Winters are cold, with snow staying on the ground for days or weeks. The growing season ranges from 75 to 150 days (Brenzel 1997). The area receives approximately $457 \mathrm{~mm}$ of rain and 1,397 $\mathrm{mm}$ of snow per year. 
Table 3. Raw values, difference values (Subject City minus Reference City, absolute values), and normalized values for Lisbon and six comparable U.S. reference cities.

\begin{tabular}{|c|c|c|c|c|c|c|c|}
\hline Criteria & Lisbon & Fort Collins & Minneapolis & Claremont & Santa Monica & Modesto & Charleston \\
\hline \multicolumn{8}{|l|}{ Tree match $(\%)$} \\
\hline Raw Value & & 46.0 & 68.5 & 16.0 & 2.3 & 37.4 & 2.1 \\
\hline Normalized Value & & 1.80 & 0.63 & 7.80 & 9.77 & 3.52 & 9.79 \\
\hline \multicolumn{8}{|l|}{$\mathrm{HDD}$ (base $18^{\circ} \mathrm{C}$ ) } \\
\hline Raw Value & 1,084 & 3,252 & 4,354 & 845 & 644 & 1,378 & 1,171 \\
\hline Difference Value & & 2,168 & 3,270 & 239 & 440 & 294 & 87 \\
\hline Normalized Value & & 4.98 & 7.51 & 0.55 & 1.01 & 0.68 & 0.20 \\
\hline \multicolumn{8}{|l|}{$\mathrm{CDD}$ (base $18^{\circ} \mathrm{C}$ ) } \\
\hline Raw Value & 474 & 379 & 383 & 856 & 310 & 1,100 & 1,183 \\
\hline Difference Value & & 95 & 91 & 382 & 164 & 626 & 709 \\
\hline Normalized Value & & 0.38 & 0.37 & 1.54 & 0.66 & 2.52 & 2.85 \\
\hline \multicolumn{8}{|l|}{ Annual Precip. (mm) } \\
\hline Raw Value & 702 & 452 & 622 & 523 & 570 & 315 & 1,555 \\
\hline Difference Value & & 250 & 80 & 179 & 132 & 387 & 853 \\
\hline Normalized Value & & 1.81 & 0.58 & 1.30 & 0.96 & 2.80 & 6.17 \\
\hline
\end{tabular}

Minneapolis, Minnesota, sits along the Mississippi River and has a humid continental climate. Winters can be very cold, with expected lows ranging from $-29^{\circ} \mathrm{C}$ to $-34^{\circ} \mathrm{C}$. Summer air masses moving north from the Gulf of Mexico can result in hot, humid weather. Annual precipitation averages 747 $\mathrm{mm}$, with nearly one-half falling in June, July, and August.

Claremont, California, is located in the valley east of Los Angeles and $70 \mathrm{~km}$ from the Pacific Ocean. The Mediterranean climate is warm during summer, when the average maximum temperature in August is $32^{\circ} \mathrm{C}$ and all-time highs reach $45^{\circ} \mathrm{C}$. Mild winters are marked by occasional frost. The annual average precipitation is $432 \mathrm{~mm}$. Winter months are wetter than summer months.

Santa Monica, California, is located along the Pacific Ocean and adjacent to Los Angeles. It has a mild marine climate with mild winters and cool summers. Record low temperatures are above $0^{\circ} \mathrm{C}$. In mid-summer, temperatures rarely exceed $30^{\circ} \mathrm{C}$. Annual precipitation averages $338 \mathrm{~mm}$ and falls primarily from November through March. Because of its oceanside location, ozone concentrations are usually lower in Santa Monica than they are inland.

Modesto, California, is located in the Central Valley and has cool, damp winters and very warm, dry summers. A layer of ground fog is common during winter. Average January temperatures are a maximum $12^{\circ} \mathrm{C}$, averaging 20 days with freezing temperatures $\left(0^{\circ} \mathrm{C}\right)$ or lower. Average July temperatures are a maximum $34.6^{\circ} \mathrm{C}$ and on average there are 80 days with highs $32^{\circ} \mathrm{C}$ or higher. Average annual rainfall is $310 \mathrm{~mm}$. Summer months are usually very dry.

Charleston, South Carolina, is located along the Atlantic Ocean in the southeast U.S. It has a humid subtropical climate with mild winters and hot, humid summers. Winter is short and mild, with temperatures seldom dropping below freezing. Summer is the wettest season; almost half of the annual rainfall occurs during the summer months in the form of thundershowers. Annual rainfall averages 1,438 mm.

\section{Compiling Data}

Street trees were sampled throughout Lisbon and the population totalled 41,247, with a standard error of 6,312 (Soares 2006). European hackberry (Celtis australis) and basswood (Tilia spp.) are the most common street trees, each accounting for $16 \%$ of the population, while black poui (Jacaranda mimosifolia) account for $10 \%$ (Table 4). Other important species belong to the sycamore (Platanus), maple (Acer), and
Table 4. Street tree inventory results for Lisbon, Portugal.

\begin{tabular}{lll}
\hline Botanical Name & No. & \% Total \\
\hline Celtis australis & 6,629 & 16.1 \\
Tilia species & 6,573 & 15.9 \\
Jacaranda mimosifolia & 4,233 & 10.3 \\
Platanus species & 3,560 & 8.6 \\
Acer negundo & 2,831 & 6.9 \\
Tipuana tipu & 1,906 & 4.6 \\
Fraxinus angustifolia & 1,177 & 2.9 \\
Ligustrum lucidum & 1,177 & 2.9 \\
Koelreuteria paniculata & 981 & 2.4 \\
Populus $\times$ canadensis & 953 & 2.3 \\
Cercis siliquastrum & 883 & 2.1 \\
Populus nigra & 813 & 2.0 \\
Brachychiton populneum & 785 & 1.9 \\
Populus alba & 757 & 1.8 \\
Aesculus hippocastanum & 687 & 1.7 \\
Celtis occidentalis & 673 & 1.6 \\
Melia azedarach & 589 & 1.4 \\
Robinia pseudoacacia & 589 & 1.4 \\
Prunus cerasifera & 519 & 1.3 \\
Grevillea robusta & 434 & 1.1 \\
Aesculus $\times$ carnea & 420 & 1.0 \\
Catalpa bignonioides & 420 & 1.0 \\
Prunus avium & 420 & 1.0 \\
Other species & 3,237 & 7.8 \\
\hline Total trees & 41,247 & 100
\end{tabular}

cottonwood (Populus) genera. Tree inventory data were assembled for each of the six reference cities (see Appendix).

Lisbon has 1,084 HDDs and $474 \mathrm{CDDs}$ with a base of $18^{\circ} \mathrm{C}$ (Energy Plus 2009) (Table 3). Average annual precipitation in Lisbon is $702 \mathrm{~mm}$ (World Climate 2010). Annual HDD, CDD, and precipitation data were compiled and shown as raw values for each reference city. Differences between Lisbon and each reference city were tabulated as absolute values (Table 3 ).

\section{Tree Matching}

The species of trees measured to develop growth curves in each reference city inventory (from Appendix) were matched at the species and genus level with the most abundant street trees in Lisbon's population (from Table 4). To quantify the extent of tree matching in each reference city, the percentage (i.e., relative abundance expressed as percentage of the population) of matching taxon in each reference city were summed (Table 3 ). 


\section{Normalizing the Values}

To normalize the values, ranges were calculated for each criterion and 10 equal intervals calculated (Table 5). For example, HDD values ranged from 0 to 4,354. Ten intervals, each 435 in size, were established and assigned the appropriate normalized value ranging from 0 to 10 .

Linear interpolation was used to calculate the normalized value for each difference value (Table 5). For example, the HDD difference value for Fort Collins is 2,168 (3,252$1,084)$. This value falls within the normalized value range of 5 to $4(1,742-2,177)$. After linear interpolation the normalized value is 4.98 , close to the value of 5.0 because the difference value 2,168 is close to the interval value of 2,177 .

\section{Accounting for Importance}

In this step, the coefficient for each criterion is weighted to reflect its relative importance. The analyst's best judgment is used to assign weighted values. If the criteria are equally important, 0.25 is assigned to each of the four coefficients. Unequal weighting can be done to accentuate or diminish the relative importance of individual criterion. The rationale for a weighting scheme applied in the Lisbon example is discussed as follows.

Table 5. Normalized interval values (first column) and corresponding difference values for each of the four criterion (subsequent columns).

\begin{tabular}{lllll}
\hline Value & $\%$ Tree Match & HDD $\left(18^{\circ} \mathrm{C}\right)$ & CDD $\left(18^{\circ} \mathrm{C}\right)$ & $\begin{array}{l}\text { Precip. }(\mathrm{mm}) \\
10-9\end{array}$ \\
\hline 10 & $>3919$ & $>2234$ & $>1243$ \\
$9-8$ & $10-15$ & $3483-3919$ & $1986-2234$ & $1105-1243$ \\
$8-7$ & $15-20$ & $3048-3483$ & $1737-1986$ & $967-1105$ \\
$7-6$ & $20-25$ & $2612-3048$ & $1489-1737$ & $829-967$ \\
$6-5$ & $25-30$ & $2177-2612$ & $1241-1489$ & $691-829$ \\
$5-4$ & $30-35$ & $1742-2177$ & $993-1241$ & $552-691$ \\
$4-3$ & $35-40$ & $1306-1742$ & $745-993$ & $414-552$ \\
$3-2$ & $40-45$ & $871-1306$ & $496-745$ & $276-414$ \\
$2-1$ & $45-50$ & $435-871$ & $248-496$ & $138-276$ \\
$1-0$ & $>50$ & $<435$ & $<248$ & $<138$ \\
\hline
\end{tabular}

\section{Matching tree species composition}

To calculate Tree Match, the percentage of each reference city population that matches Lisbon's population at the species and genus levels is summed. A species-to-species match is most desirable, but frequently a different species of the same genus will have similar growth rate, habit, and mature size. For example, European hackberry (Celtis australis) is the most abundant species in Lisbon but was not measured in any reference cities. However, Chinese hackberry (Celtis sinensis), common hackberry (Celtis occidentalis), and sugarberry (Celtis laevigata), were measured in reference cities and can be considered to match European hackberry at the genus level because they all grow at a moderate rate to be large, deciduous shade trees.

The two reference cities that best match Lisbon in terms of species composition are Minneapolis, $\mathrm{MN}$, and Fort Collins, $\mathrm{CO}$ (Table 3). They are the only two cities with matches for both hackberry and basswood, which account for 34\% of Lisbon's street tree population. Green ash (Fraxinus pennsylvanica), the most common street tree species in both Minneapolis and Fort Collins, can match with narrowleaf ash (Fraxinus angustifolia) in Lisbon because both are medium-stature shade trees. Minneapolis has five species of maple that match boxelder (Acer negundo), which comprises 7\% of Lisbon's population. In Fort Collins, three species of maple match with Lisbon's box elder. Fort Collins' Great Plains cottonwood (Populus sargentii) can match with Lisbon's Carolina, white, and black cottonwoods (Populus $\times$ Canadensis, P. alba, P. nigra). Also, Fort Collins' plums (Prunus spp.) can match with Lisbon's cherry plum and sweet cherry (Prunus cerasifera, P. avium). The total percentage of Lisbon's tree population matched by the tree species measured in Minneapolis and Fort Collins is $68.5 \%$ and $46 \%$, respectively (Table 3 ).

The three California reference cities have measured trees that match at the species and genus levels, as well as climates that are more similar to Lisbon's because their winter seasons are warmer. Modesto has nine matches accounting for $37.2 \%$ of Lisbon's street tree population. Claremont (6 matches, $16 \%$ ), and Santa Monica (1 match, 2.3\%) have matches as well (Table 3). Charleston, SC, has three tree matches $(2.1 \%)$.

Tree Match is weighted 0.1 in this assessment, and considered the least important variable. The rationale is that Lisbon's tree population is a mix of deciduous species from northern Europe and broadleaf evergreens from the Mediterranean region. Although Minneapolis and Fort Collins provide the most matches, their populations lack the Mediterranean species. Perhaps more importantly, their tree grow rates are unlikely to be a close match because of their much shorter growing seasons. By selecting a low weight for Tree Match the effect of these confounding factors is minimized.

\section{Matching HDDs and CDDs}

The large HDD numbers and corresponding differences between Lisbon and reference cities can be misleading. Effects of trees on heating savings are small per HDD and much greater per CDD. The magnitude of this difference is on the order of 10 , largely because trees can increase winter heating loads by obstructing irradiance, as well as reduce heating loads. To obtain a rough estimate of how this difference influences tree energy savings, divide HDDs (base $18^{\circ} \mathrm{C}$ ) by 1,000 and CDDs by 100 . For Lisbon, HDDs convert from 1,084 to 1.08, and CDDs convert from 474 to 4.74 (Table 3). Annual cooling savings from trees will be approximately 4 to 5 times greater than heating savings on an average per tree basis. This conversion is a very rough approximation because actual results will be influenced by tree sizes, locations, building vintage, types of heating and cooling equipment, and the prices of electricity and natural gas.

Because of Lisbon's relatively mild climate, energy savings from trees will not be large, so this benefit should not dominate selection. Claremont and Santa Monica provide the best match when both HDDs and CDDs are considered, and Santa Monica is closer than Claremont when considering CDD. Although CDDs are relatively more important than HDDs in Lisbon, and Fort Collins and Minneapolis provide the best match in terms of CDDs, their HDDs are so much greater than Lisbon's that heating savings would be grossly overestimated. So as not to overstate heating savings, the HDD variable is weighted 0.3 , which accentuates the difference between cities with HDDs that are much greater than Lisbon's and those with HDDs closer to Lisbon's. The CDD variable is weighted 0.2 because even air conditioning savings will be relatively small in this benign climate. 


\section{Matching annual precipitation}

From the perspective of estimating rainfall interception, annual precipitation for Minneapolis provides the best match to Lisbon, followed by Santa Monica and Claremont (Table 3). Although not shown by these annual data, both Santa Monica and Claremont are Mediterranean climate cities with a seasonal rainfall pattern that is more similar to Lisbon than Minneapolis. Results from all three cities are likely to underestimate actual interception by Lisbon's trees because annual precipitation totals are less. Annual precipitation is weighted 0.4 reflecting its relatively high importance in selecting a reference city.

\section{Final Analysis}

When coefficients are weighted equally, the best matching reference cities are Modesto (RMSE = 2.6) and Fort Collins (2.8) (Table 6). The worst matches are Charleston (5.96), Santa Monica (4.95), and Claremont (4.04), due largely to inferior tree matching.

Weighting the coefficients unequally gives a different result. Tree matching is considered relatively unimportant in this analysis (0.1), while HDD (0.3) and annual precipitation are weighted as most important (0.4). Because of this unequal weighting, the Mediterranean climate cities Modesto (RMSE $=2.41$ ) and Claremont (2.71) are the best choices for use with Lisbon's tree inventory in i-Tree Streets (Table 6). Fort Collins (3.02) and Santa Monica (3.21) are better fits than Minneapolis (4.14) and Charleston (5.15). Although Modesto is the best choice using both equal and unequal weighting, Claremont jumped from fourth- to second-best choice with unequal weighting. Weighting that accentuated the importance of HDDs emphasized the large difference in HDDs between Fort Collins and Lisbon (2,168 HDDs) relative to Claremont
(845 HDDs). The relatively low weighting for tree matching also advantaged Claremont relative to Fort Collins and Minneapolis. The winter season rainfall pattern, summer irrigation, and longer growing season in Modesto and Claremont are likely to result in tree growth patterns more similar to those found in Lisbon than those found in Minneapolis and Fort Collins.

\section{CONCLUSION}

This approach to selecting reference cities provides a systematic way to compare and determine what the best match for a subject city is. The analyst can weight individual criterion to reflect its relative importance. Additional criteria can be added to the assessment and weighted as well.

Reference city selection may be complicated in the future by changing climate due to greenhouse gases and urban heat islands. The magnitude of change will vary geographically, making long-term weather data less reliable in areas experiencing the greatest changes. Analysts may need to consider the role of changing climate on their subject city and candidate reference cities during the selection process.

In the future, i-Tree Streets and i-Tree Eco are likely to be integrated into a single program with input variables such as hourly meteorological data and air pollutant concentrations for every major city stored in a database. However, data on tree size and growth still will be needed for regional "reference cities" outside the U.S. because of differences in species composition, climate, soils, growing conditions, and maintenance practices. To that end, the USDA Forest Service is sharing its reference city data collection protocols and experience with scientists in Australia, Asia, Canada, and Europe to develop a worldwide data network.

Table 6. Root Mean Square Errors calculated with coefficients weighted equally $(0.25$ each) and unequally for each criterion.

\begin{tabular}{llllll}
\hline Weighting & Fort Collins & Minneapolis & Claremont & Santa Monica & Modesto \\
\hline Equal & 2.80 & 3.78 & 4.04 & 4.95 & 2.60 \\
Unequal & 3.02 & 4.14 & 2.71 & 3.21 & 5.96 \\
\hline
\end{tabular}

Unequal: Tree Match $=0.1, \mathrm{CDD}=0.2, \mathrm{HDD}=0.3$, Annual Precipitation $=0.4$ 


\section{LITERATURE CITED}

Bailey, R.G. 2002. Ecoregion-based Design for Sustainability. SpringerVerlag, New York. 222 pp.

Breckle, S.W. 1999. Walter's Vegetation of the Earth (4th Edition). Springer, Berlin, $527 \mathrm{p}$.

Brenzel, K.N. (Ed.). 1997. National Garden Book. 1st Edition Sunset Books, Inc., Menlo Park, CA. 656 pp.

Degree Days. 2009. Degree Days.net - Custom Degree Day Data. Accessed 12/14/2009. <http://www.degreedays.net>.

EnergyPlus Energy Simulation Software. 2009. Weather Data. Accessed 12/4/2009. <http://www.eere.energy.gov/buildings/energyplus/cfm/ weather_data3.cfm/region=6_europe_wmo_region_6/country=PRT/ cname $=$ Portugal $>$.

i-Tree. 2009. i-Tree Software Suite User's Manual. Accessed 12/9/2009. $<\mathrm{http}: / /$ www.itreetools.org $>$.

Kling, J. 2008. Greener cities: U.S. Forest Service software package helps cities manage their urban treescape. PSW Science Perspectives. USDA Forest Service, Pacific Southwest Research Station. Albany, CA. 6 pp.

Maco, S.E., and E.G. McPherson. 2003. A practical approach to assessing structure, function, and value of street tree populations in small communities. Journal of Arboriculture. 29(2):84-97.

McPherson, E.G. 1992. Accounting for benefits and costs of urban greenspace. Landscape and Urban Planning. 22:41-51.

McPherson, E.G., and J.R. Simpson. 2002. A comparison of municipal forest benefits and costs in Modesto and Santa Monica, CA, USA. Urban Forestry \& Urban Greening 1(2002):61-74.

McPherson, E.G., J.R. Simpson, and P.J. Peper. 2005. Municipal forest benefits and costs in five US cities. Journal of Forestry 12:411-416.

National Tree Benefit Calculator. 2009. Accessed 12/3/2009. <http:// www.treebenefits.com>.

Peper, P.J., and E.G. McPherson. 2003. Evaluation of four methods for estimating leaf area of isolated trees. Urban Forestry \& Urban Greening. 2(1):19-29.

Scott, K.I., E.G. McPherson, and J.R. Simpson. 1998. Air pollutant uptake by Sacramento's urban forest. Journal of Arboriculture. 24(4):224-234.

Simpson, J.R. 2002. Improved estimates of tree shade effects on residential energy use. Energy and Buildings. 34:1067-1076.

Soares, A.L. 2006. Tree value assessment: Lisbon urban forest. Landscape Architecture Ph.D. Dissertation. Instituto Superior de Agronomia, Universidade Tecnica de Lisboa, Lisboa. 344 pp.

World Weather. 2009. World Weather Information Service. Accessed 12/2/2009. <http://www.worldweather.org>.

World Climate. 2010. Buttle and Turtle, Ltd. <www.worldclimate.com>.

Xiao, Q., E.G. McPherson, S.L. Ustin, and M.E. Grismer. 2000. A new approach to modeling tree rainfall interception. Journal of Geophysical Research. 105:29,173-29,188.

E. Gregory McPherson

USDA Forest Service

Pacific Southwest Research Station

1731 Research Park Dr.

Davis, CA 95618, U.S.
Résumé. Le programme informatique i-Tree Streets (anciennement STRATUM) quantifie la structure de la forêt municipale, sa fonction et sa valeur au moyen de données sur la croissance des arbres et de données géographiques provenant de 16 villes références américaines, une pour chacune des 16 zones climatiques. Sélectionner la ville de référence qui ressemble le plus à la cité à évaluer s'avère problématique lorsque la ville est située hors des États-Unis, est située près de la limite entre deux zones climatiques ou encore si elle a un climat ou une composition en arbres différent en raison de différences au niveau de l'altitude, de la morphologie urbaine et de la qualité environnementale. Un processus systématique de sélection de la meilleure ressemblance est décrit et illustré pour Lisbonne au Portugal. Les critères de sélection sont la composition en espèces d'arbres, le nombre de degrés-jour de réchauffement et de rafraichissement, et la quantité de précipitations annuelles. Les valeurs brutes et les différences de valeur pour chacun des critères sont normalisées sur une échelle de 0 à 10 au moyen d'une interpolation linéaire. Le coefficient pour chacun des critères est ajusté pour refléter son importance relative. Le RMSE est calculé et la ville de référence avec la plus faible valeur devient celle qui correspond le mieux avec celle à évaluer. Les villes de référence de Modesto $(\mathrm{RMSE}=2,41)$ et de Claremont $(\mathrm{RMSE}=2,71)$ en Californie sont celles qui correspondaient le mieux avec celle de Lisbonne lorsque les coefficients étaient soupesés de manière inégale.

Zusammenfassung. Das iStreet Computer-Programm (früher STRATUM) quantifiziert die kommunale Forststruktur, Funktion und Wert, indem es Baumwachstumsraten und geographische Daten aus 16 amerikanischen Referenzstädten verwendet, je eine aus einer der 16 definierten Klimazonen. Die Auswahl der am besten zutreffenden Referenzstadt ist problematisch, wenn die betroffene Stadt ausserhalb der USA liegt, oder zwischen zwei Klimazonen oder sie hat ein anderes Klima oder Baumartenzusammensetzung, weil unterschiedliche Höhenlagen, urbane Morphologie und Umweltqualität bestehen. Ein systematischer Prozess, die beste Referenzstadt auszuwählen, wird hier am Beispiel von Lissabon, Portugal, beschrieben und illustriert. Die Selektionskriterien sind Baumartenzusammensetzung, Hitze und Abkühlung während des Tages und jährlicher atmosphärischer Niederschlag. Grobe und unterschiedliche Werte für jedes Kriterium wurden durch lineare Interpolation normalisiert, um von 1 bis $10 \mathrm{zu}$ rangieren. Der Coeffizient für jades Kriterium ist gewichtet, um seine relative Bedeutung zu wichten. Der RSME wurde berechnet und die Referenzstadt mit dem niedrigsten Wert ist die beste Auswahl für die gegenständliche Stadt (hier: Lissabon). Die kalifornischen Referenzstädte Modesto (RSME $=2,41$ ) und Claremont $(2,71)$ haben sich als die besten Referenzen für Lissabon herausgestellt, wenn die Coeffizienten ungleich gewichtet werden.

Resumen. El programa de cómputo i-Tree Streets (STRATUM) cuantifica la estructura del bosque municipal, función, y valor usando el crecimiento del árbol y datos geográficos de 16 ciudades de los Estados Unidos, una en cada una de las 16 zonas climáticas. Se seleccionó la ciudad de referencia que mejor se ajustó. Esto es problemático cuando la ciudad está fuera de los Estados Unidos, o en el límite de dos zonas climáticas, o tiene un clima diferente o composición de especies debido a diferencias en elevación, morfología urbana, o calidad ambiental. Se describe e ilustra un proceso sistemático para ubicar la mejor selección para Lisboa, Portugal. Los criterios de selección son composición de especies de árboles, días de calor y fríos y precipitación anual. Los valores para cada criterio son normalizados a rangos entre 0 a 10 usando interpolación lineal. El coeficiente para cada criterio es ponderado para reflejar su importancia relativa. El Error Cuadrado Medio (RMSE) es calculado y la ciudad de referencia con el valor más bajo de la ciudad estudiada. Las ciudades californianas de Modesto $(\mathrm{RMSE}=2.41)$ y Claremont $(2.71)$ probaron ser las que mejor ajustaron para Lisboa donde los coeficientes fueron compensados desigualmente. 


\section{APPENDIX. TREE SPECIES MEASURED IN EACH OF SIXTEEN U.S. REFERENCE CITIES AND THEIR RELATIVE ABUNDANCE (\%).}

\begin{tabular}{ll} 
North & \\
Fort Collins, CO & \\
Measured species & Pop \\
\hline Fraxinus pennsylvanica & 21.6 \\
Gleditisia triacanthos & 10.2 \\
Tilia cordata & 6.7 \\
Quercus macrocarpa & 6.6 \\
Celtis occidentalis & 5.6 \\
Malus spp. & 4.7 \\
Ulmus americana & 4.4 \\
Acer platanoides & 2.9 \\
Ulmus pumila & 2.8 \\
Tilia americana & 2.4 \\
Acer saccharinum & 1.8 \\
Fraxinus americana & 1.7 \\
Populus sargentii & 1.4 \\
Pinus nigra & 1.2 \\
Gymnocladus dioicus & 1.1 \\
Pyrus sp. & 1.0 \\
Prunus sp. & 1.0 \\
Picea pungens & 0.9 \\
Acer saccharum & 0.9 \\
Pinus ponderosa & 0.8 \\
\% of total population & 79.7
\end{tabular}

Pacific Northwest

Longview, WA

Measured species

Prunus cerasifera 13.9

'Thundercloud'

Prunus serrulata $\quad 13.1$

Betula pendula $\quad 8.8$

Liquidambar styraciflua $\quad 6.0$

Carpinus betulus $\quad 5.7$

'Fastigiata'

Ulmus americana $\quad 4.6$

Acer platanoides $\quad 3.7$

Crataegus laevigata $\quad 3.4$

Quercus rubra $\quad 2.1$

Populus balsamifera ssp. $\quad 1.7$

trichocarpa

Malus angustifolia $\quad 1.3$

Tilia cordata $\quad 1.3$

Acer saccharum $\quad 1.2$

Tilia americana $\quad 1.2$

Fraxinus latifolia $\quad 1.0$

Acer rubrum $\quad 1.0$

Acer macrophyllum $\quad 0.9$

Fagus sylvatica $\quad 0.9$

'atropunicea'

Morus alba

Pinus contorta 0.5

'Bolanderi'

Pseudotsuga menziesii

$\%$ of total population

0.4

74.1

\section{Interior West}

Albuquerque, NM

Gleditsia triacanthos

Fraxinus velutina

Ulmus pumila

Platanus hybrida

Chilopsis linearis

Pinus nigra

Fraxinus pennsylvanica

Elaeagnus angustifolia

Pyrus calleryana

Pinus sylvestris

Malus spp.

Prunus cerasifera

Pinus edulis

Fraxinus americana

Populus fremontii

Populus angustifolia

Fraxinus angustifolia

Pinus ponderosa

Koelreuteria paniculata

Pistacia chinensis

$\%$ of total population

\section{Inland Valleys \\ Modesto, CA}

Measured species

Fraxinus velutina 'Modesto'

$\%$ Pop

Pistacia chinensis

13.7

Zelkova serrata

10.6

Fraxinus angustifolia 'Raywood' 5.1

Pyrus calleryana 'Bradford'

5.1

Ginkgo biloba

Fraxinus holotricha

Gleditsia triacanthos

Celtis sinensis

Liquidambar styraciflua

Fraxinus excelsior 'Hessei' $\quad 3.2$

Fraxinus pennsylvanica 'Marshall' 3.1

Platanus hybrida 2.7

Cinnamomum camphora $\quad 1.7$

Magnolia grandiflora

Quercus ilex

Koelreuteria paniculata

1.2

0.8

Pinus thunbergiana

Betula pendula

Lagerstroemia indica
Measured species

Acer saccharinum

Temperate Interior West

Boise, ID

Measured species

Acer platanoides

Acer saccharinum $\%$ Pop

Gleditsia triacanthos

Fraxinus pennsylvanica

Malus spp.

Fraxinus americana

Pyrus calleryana

Platanus occidentalis

Tilia americana

Liquidambar styraciflua

Robinia pseudoacacia

Pinus sylvestris

Quercus rubra

Picea pungens

Juglans nigra

Crataegus spp.

Acer saccharum

Catalpa speciosa

Platanus hybrida

Ulmus pumila

$\%$ of total population

\section{Southwest Desert \\ Glendale, AZ}

Measured species

Ulmus parvifolia

Fraxinus velutina

Pinus eldarica

Prosopis chilensis

Acacia salicina

Washingtonia robusta $\quad 4.9$

Quercus virginiana $\quad 4.4$

Olea europaea $\quad 3.6$

Pinus halepensis

Cercidium floridum

Phoenix dactylifera

Eucalyptus microtheca

Washingtonia filifera

Fraxinus uhdei

Rhus lancea

Acacia farnesiana

Pistacia chinensis

Morus alba

Brachychiton populneum

Parkinsonia aculeata 


\begin{tabular}{ll}
$\begin{array}{l}\text { Southern California Coast } \\
\text { Santa Monica, CA }\end{array}$ \\
Measured species & $\%$ Pop \\
\hline Washingtonia robusta & 13.3 \\
Ficus thonningii & 11.6 \\
Magnolia grandiflora & 6.5 \\
Phoenix canariensis & 5.3 \\
Podocarpus & 4.8 \\
macrophyllus & \\
Ceratonia siliqua & 3.2 \\
Cupaniopsis & 3.1 \\
anacardioides & \\
Pinus canariensis & 3.0 \\
Liquidambar styraciflua & 2.7 \\
Cedrus deodara & 2.6 \\
Metrosideros excelsus & 2.5 \\
Melaleuca quinquenervia & 2.4 \\
Cinnamomum camphora & 2.3 \\
Jacaranda mimosifolia & 2.3 \\
Callistemon citrinus & 2.2 \\
Tristaniopsis conferta & 1.7 \\
Schinus terebinthifolius & 1.6 \\
Pittosporum undulatum & 1.5 \\
Eucalyptus ficifolia & 1.0
\end{tabular}

$\%$ of total population $\quad 73.6$

\begin{tabular}{ll}
$\begin{array}{l}\text { Tropical } \\
\text { Honolulu, HI }\end{array}$ & \\
Measured species & $\%$ Pop \\
\hline Cassia $\times$ nealiae & 7.6 \\
Tabebuia heterophylla & 6.9 \\
Cocos nucifera & 6.1 \\
Filicium decipiens & 4.1 \\
Veitchia merrillii & 3.9 \\
Lagerstroemia speciosa & 3.7 \\
Samanea saman & 3.1 \\
Tabebuia aurea & 3.0 \\
Conocarpus erectus & 2.7 \\
var. argenteus & \\
Delonix regia & 2.6 \\
Elaeodendron orientale & 2.6 \\
Ilex paraguariensis & 1.9 \\
Melaleuca quinquenervia & 1.7 \\
Tabebuia ochracea ssp. & 1.5 \\
neochrysantha & \\
Calophyllum inophyllum & 1.4 \\
Cordia subcordata & 1.1 \\
Casuarina equisetifolia & 1.0 \\
Bauhinia $\times$ blakeana & 0.9 \\
Citharexylum spinosum & 0.9 \\
Ficus benjamina & 0.7 \\
Swietenia mahogani & 0.6 \\
\% of total population & 57.9
\end{tabular}

\section{Northern California Coast \\ Berkeley, CA}

Measured species

Platanus hybrida

Liquidambar styraciflua

Quercus agrifolia

Prunus cerasifera

Cinnamomum camphora

Pyrus kawakamii

Sequoia sempervirens

Magnolia grandiflora

Ulmus americana

Pittosporum undulatum

Pistacia chinensis

Fraxinus velutina

Acer palmatum

Ulmus parvifolia

Pyrus calleryana

Ginkgo biloba

Robinia pseudoacacia

Liriodendron tulipifera

Acacia melanoxylon

Pinus radiata

Eucalyptus globulus

$\%$ of total population

\section{Central Florida \\ Orlando, FL}

Measured species

Quercus virginiana

Lagerstroemia indica

Quercus laurifolia

Sabal palmetto

Ulmus parvifolia

Magnolia grandiflora

Acer rubrum

Quercus shumardii

Washingtonia robusta $\%$ Pop

7.4

6.5

6.4

4.1

3.1

1.7

1.7

1.6

1.5

1.4

1.4

1.4

1.3

1.2

1.2

1.1

1.1

1.1
0.7

0.5

50.1

Pinus elliottii

Cinnamomum camphora

Syagrus romanzoffiana

Prunus caroliniana

Platycladus orientalis

Triadica sebifera

Koelreuteria elegans

Eriobotrya japonica

Liquidambar styraciflua

Platanus occidentalis

Juniperus virginiana var. silicicola 0.3

$\%$ of total population
Inland Empire

Claremont, CA

Measured species

Lagerstroemia indica

Quercus ilex 4.3

Quercus agrifolia $\quad 4.2$

Pinus canariensis $\quad 4.0$

Jacaranda mimosifolia $\quad 4.0$

Platanus racemosa $\quad 3.9$

Fraxinus velutina 'Modesto' 2.8

Platanus hybrida $\quad 2.6$

Eucalyptus sideroxylon $\quad 2.5$

Pistacia chinensis $\quad 2.2$

Liriodendron tulipifera $\quad 2.1$

Magnolia grandiflora $\quad 1.9$

Pinus brutia $\quad 1.8$

Ginkgo biloba $\quad 1.6$

Fraxinus uhdei $\quad 1.5$

Cinnamomum camphora $\quad 1.2$

Brachychiton populneum $\quad 1.2$

Washingtonia robusta $\quad 1.1$

Schinus terebinthifolius $\quad 1.0$

Schinus molle $\quad 0.9$

Pyrus calleryana $\quad 0.8$

$\%$ of total population $\quad 63.6$

\section{Coastal Plain}

Charleston, SC

Measured species

Quercus virginiana $\%$ Pop

Lagerstroemia indica

Sabal palmetto $\quad 19.5$

Quercus nigra $\quad 5.1$

Quercus laurifolia $\quad 3.9$

Cornus florida $\quad 2.3$

Pinus taeda $\quad 1.8$

Butia capitata $\quad 1.5$

Acer rubrum

1.0

Magnolia grandiflora $\quad 0.8$

Gleditsia triacanthos $\quad 0.8$

Quercus phellos $\quad 0.8$

Ilex opaca $\quad 0.7$

Liquidambar styraciflua $\quad 0.7$

Juniperus virginiana $\quad 0.6$

Celtis laevigata $\quad 0.6$

Platanus occidentalis $\quad 0.5$

Pyrus calleryana $\quad 0.5$

Carya illinoinensis $\quad 0.3$

$\%$ of total population

84.9 


\section{APPENDIX. TREE SPECIES MEASURED IN EACH OF SIXTEEN U.S. REFERENCE CITIES AND THEIR RELATIVE ABUNDANCE (\%).}

\begin{tabular}{ll} 
South & \\
Charlotte, NC & \\
Measured species & Pop \\
\hline Quercus phellos & 16.7 \\
Lagerstroemia spp. & 14.1 \\
Acer rubrum & 6.7 \\
Cornus florida & 5.3 \\
Acer saccharum & 3.5 \\
Prunus spp. & 2.9 \\
Juniperus virginiana & 2.4 \\
Acer saccharinum & 2.4 \\
Liquidambar styraciflua & 2.2 \\
Pinus echinata & 1.3 \\
Malus spp. & 1.2 \\
Ilex opaca & 1.1 \\
Pinus taeda & 1.1 \\
Pyrus calleryana & 1.0 \\
Prunus yedoensis & 1.0 \\
Quercus nigra & 1.0 \\
Quercus alba & 0.9 \\
Magnolia grandiflora & 0.9 \\
Quercus rubra & 0.9 \\
Betula nigra & 0.9 \\
Ulmus alata & 0.3 \\
\% of total population & 67.9
\end{tabular}

\begin{tabular}{ll}
$\begin{array}{l}\text { Midwest } \\
\text { Minneapolis, MN }\end{array}$ & \\
Measured species & $\%$ Pop \\
\hline Fraxinus pennsylvanica & 20.0 \\
Ulmus americana & 14.0 \\
Acer platanoides & 12.5 \\
Acer saccharum & 10.9 \\
Tilia cordata & 10.4 \\
Celtis occidentalis & 6.4 \\
Gleditsia triacanthos & 6.4 \\
Tilia americana & 5.2 \\
Ginkgo biloba & 2.3 \\
Malus spp. & 1.8 \\
Acer rubrum & 1.8 \\
Quercus palustris & 1.6 \\
Acer saccharinum & 0.8 \\
Fraxinus americana & 0.3 \\
Quercus rubra & 0.2 \\
Acer negundo & 0.2 \\
Ulmus pumila & 0.2 \\
\% of total population & 95.1
\end{tabular}

$\begin{array}{llll}\begin{array}{l}\text { Northeast } \\ \text { Queens, NY }\end{array} & \text { \% Pop } & & \begin{array}{l}\text { Lower Midwest } \\ \text { Indianapolis, IN }\end{array} \\ \text { Measured species } & 26.9 & & \text { Acer saccharinum } \\ \text { Acer platanoides } & 15.1 & \text { Acer saccharum } & 13.9 \\ \text { Platanus hybrida } & 9.3 & \text { Celtis } \text { occidentalis } & 6.0 \\ \text { Quercus palustris } & 6.1 & \text { Malus spp. } & 5.1 \\ \text { Gleditsia triacanthos } & 5.9 & \text { Fraxinus americana } & 4.9 \\ \text { Tilia cordata } & 5.7 & \text { Ulmus pumila } & 4.9 \\ \text { Acer saccharinum } & 5.5 & \text { Acer platanoides } & 3.4 \\ \text { Pyrus calleryana } & 4.3 & \text { Pinus strobus } & 2.8 \\ \text { Fraxinus pennsylvanica } & 2.0 & \text { Acer rubrum } & 2.7 \\ \text { Acer rubrum } & 2.0 & \text { Morus spp. } & 2.7 \\ \text { Ginkgo biloba } & 1.8 & \text { Fraxinus pennsylvanica } & 2.6 \\ \text { Acer saccharum } & 1.4 & \text { Picea pungens } & 2.4 \\ \text { Zelkova serrata } & 1.0 & \text { Cercis canadensis } & 2.3 \\ \text { Quercus rubra } & 0.8 & \text { Quercus rubra } & 1.7 \\ \text { Liquidambar styraciflua } & 0.7 & \text { Gleditsia triacanthos } & 1.7 \\ \text { Tilia tomentosa } & 0.7 & \text { Populus deltoides } & 1.6 \\ \text { Ulmus americana } & 0.5 & \text { Juglans nigra } & 1.6 \\ \text { Prunus serrulata } & 0.2 & \text { Pyrus calleryana } & 1.3 \\ \text { Aesculus hippocastanum } & 0.2 & \text { Catalpa speciosa } & 1.2 \\ \text { Quercus phellos } & 0.1 & \text { Tilia cordata } & 1.0 \\ \text { Malus spp. } & 0.1 & & 0.9 \\ \text { Pinus strobus } & 90.5 & \text { \% of total population } & 64.5 \\ \text { \% of total population } & & & \end{array}$

